\title{
$\beta 3$-integrin-deficient mice are a model for Glanzmann thrombasthenia showing placental defects and reduced survival
}

\author{
Kairbaan M. Hodivala-Dilke, ${ }^{1}$ Kevin P. McHugh, ${ }^{2}$ Dimitrios A. Tsakiris, ${ }^{3}$ \\ Helen Rayburn, ${ }^{1}$ Denise Crowley, ${ }^{1}$ Mollie Ullman-Culleré, ${ }^{1}$ F. Patrick Ross, ${ }^{2}$ \\ Barry S. Coller, ${ }^{3}$ Steven Teitelbaum, ${ }^{2}$ and Richard O. Hynes ${ }^{1}$
}

${ }^{1}$ Howard Hughes Medical Institute, Center for Cancer Research and Department of Biology, Massachusetts Institute of Technology, Cambridge, Massachusetts 02139, USA

${ }^{2}$ Department of Pathology, Washington University School of Medicine, St. Louis, Missouri 63110, USA

${ }^{3}$ Department of Medicine, Mount Sinai School of Medicine, New York, New York 10029, USA

Address correspondence to: R.O. Hynes, Massachusetts Institute of Technology, 77 Massachusetts Avenue, E17-227, Cambridge, Massachusetts 02139, USA. Telephone: (617) 253-6422; Fax: (617) 253-8357; E-mail: rohynes@mit.edu

Received October 12, 1998, and accepted in revised form December 11, 1998.

\begin{abstract}
$\beta 3$ integrins have been implicated in a wide variety of functions, including platelet aggregation and thrombosis $(\alpha \operatorname{IIb} \beta 3)$ and implantation, placentation, angiogenesis, bone remodeling, and tumor progression $(\alpha v \beta 3)$. The human bleeding disorder Glanzmann thrombasthenia $(\mathrm{GT})$ can result from defects in the genes for either the $\alpha$ IIb or the $\beta 3$ subunit. In order to develop a mouse model of this disease and to further studies of hemostasis, thrombosis, and other suggested roles of $\beta 3$ integrins, we have generated a strain of $\beta 3$-null mice. The mice are viable and fertile, and show all the cardinal features of GT (defects in platelet aggregation and clot retraction, prolonged bleeding times, and cutaneous and gastrointestinal bleeding). Implantation appears to be unaffected, but placental defects do occur and lead to fetal mortality. Postnatal hemorrhage leads to anemia and reduced survival. These mice will allow analyses of the other suggested functions of $\beta 3$ integrins and we report that postnatal neovascularization of the retina appears to be $\beta 3$-integrin-independent, contrary to expectations from inhibition experiments.
\end{abstract}

J. Clin. Invest. 103:229-238 (1999)

\section{Introduction}

The $\beta 3$ subfamily of integrins comprises $\alpha \mathrm{IIb} \beta 3$ (glycoprotein IIbllla) and $\alpha v \beta 3$ (1), and these integrins have been implicated in a wide variety of important physiological and pathological functions. $\alpha \operatorname{IIb} \beta 3$ is expressed only on platelets and megakaryocytes and is essential for platelet aggregation. It also controls platelet function in thrombosis and hemostasis (2-4). $\alpha \mathrm{v} \beta 3$ is expressed on many cell types, including platelets (5), osteoclasts (6) fibroblasts, some metastatic melanomas (7), and endothelial cells (8). Common ligands for $\alpha \operatorname{IIb} \beta 3$ and $\alpha v \beta 3$ include fibrinogen, fibronectin, von Willebrand factor, thrombospondin, and vitronectin (9). In addition, $\alpha v \beta 3$ also recognizes osteopontin, bone sialoprotein, plasminogen activator inhibitor-1 (10), cell adhesion molecule L1 on neurites (11, 12 ), and a fragment of metalloproteinase 2 (13).

Upon platelet stimulation, surface $\alpha \operatorname{IIb} \beta 3$ becomes activated, binds fibrinogen and von Willebrand factor, and gives rise to platelet aggregation. Glanzmann thrombasthenia (GT) is a relatively rare hereditary hemorrhagic disorder characterized by a severe reduction in, or absence of, platelet aggregation in response to multiple physiologic agonists. GT is the result of qualitative or quantitative changes in $\alpha \mathrm{IIb}$ or $\beta 3$. Studies on platelets from thrombasthenic patients show reduced fibrinogen uptake and reduced clot retraction. GT patients with defects in the $\beta 3$ gene have deficiencies in both $\alpha \operatorname{IIb} \beta 3$ and $\alpha v \beta 3$, whereas patients with defects in $\alpha$ IIb have defects only in $\alpha \operatorname{IIb} \beta 3(14,15)$. Both groups have similar clinical phenotypes characterized primarily by mucocutaneous hemorrhage. Thus, the effect of $\alpha \operatorname{IIb} \beta 3$ on platelet function is relatively clear but, as yet, the effect of $\alpha v \beta 3$ dysfunction on platelets and other cell types is still to be assessed. Observational studies and antibody and peptide blocking experiments have implicated $\alpha v \beta 3$ in several physiological roles including embryo implantation, angiogenesis, and bone resorption.

During embryo implantation, the quiescent, nonadherent trophectoderm cells undergo a major transformation in which they initiate protrusive activity and become adhesive to extracellular matrix. Although this process coincides with $\alpha v \beta 3$ expression (16), the dependency of trophoblast invasion on $\alpha v \beta 3$ function is unclear. During adult life, angiogenesis is mainly restricted to the female reproductive cycle, wound healing, and tumor growth (17). There is a wealth of new information bearing on the role of angiogenesis in tumor growth and the potential role of $\alpha v \beta 3$ in angiogenesis (for reviews, see 18, 19). In particular, examples of disruption of angiogenesis using antagonists of $\alpha v \beta 3$ have been reported $(13,20-22)$.

Retinal neovascularization is a major cause of visual loss in a variety of ocular diseases, including retinopathy of prematurity, senile macular degeneration, and diabetic retinopathy, and involvement of $\alpha v \beta 3$ in these diseases has been suggested (23). $\alpha v \beta 3$ was observed on blood ves- 
a
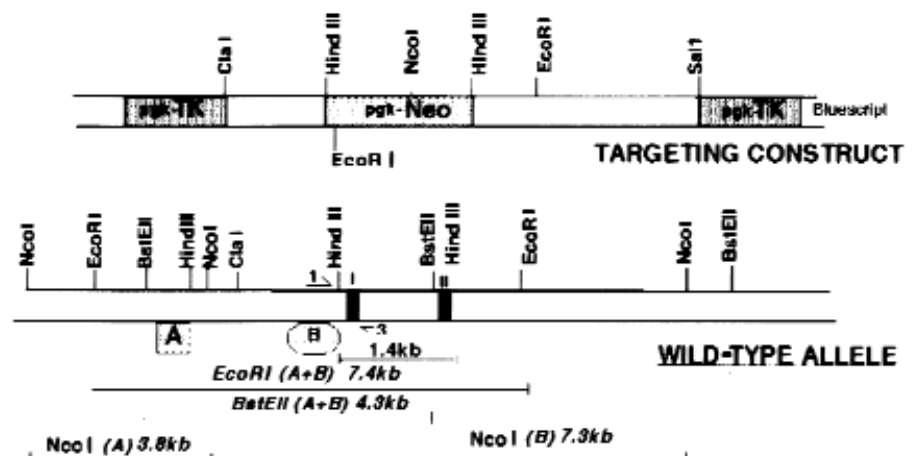

Neol (A) $3.8 \mathrm{~kb}$

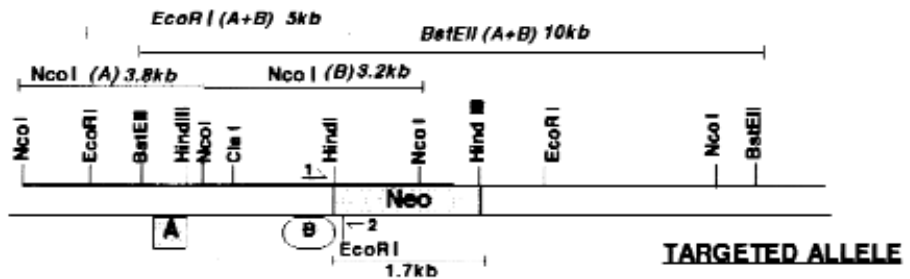

$b$

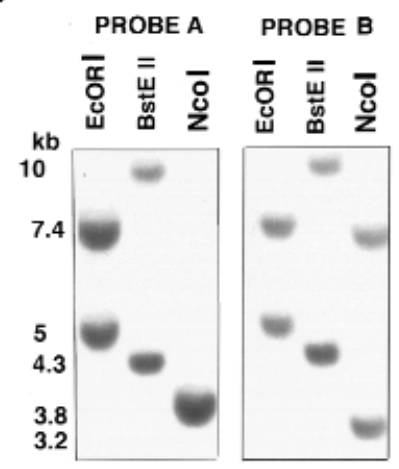

$\boldsymbol{C}$

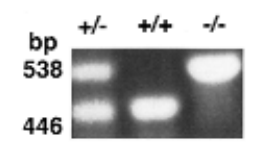

Figure 1

Targeting strategy, Southern blots and PCR analysis of ES cells and mice lacking the $\beta 3$-integrin gene. (a) Structure of $\beta 3$ targeting construct, wildtype $\beta 3$ allele and targeted $\beta 3$ allele. Exons are indicated as black boxes. The $1.7 \mathrm{~kb}$ pgk-neomycin-resistance cassette replaces a $1.4 \mathrm{~kb}$ HindlII fragment of the $\beta 3$-gene including exons I and II. Pgk-thymidine kinase genes were used for negative selection. (b) Southern blot analysis of EcoRI, BstEII and Ncol-digested genomic DNA from a representative targeted clone (111). Probe A lay $5^{\prime}$ of the targeting construct and probe B lay inside it (a). (c) PCR analysis of wild-type, heterozygous and $\beta 3$-null tail DNA used to screen offspring. Primer locations are indicated by half arrows in A and give products of 446 bp with primers 1 and 3 (wild-type) or 538 bp with primers 1 and 2 (mutant).

sels in ocular tissue with active neovascularization or with age-related macular degeneration. Murine retinal blood vessel development is initiated shortly before birth and proceeds for approximately two weeks postnatally. During this time, $\alpha v \beta 3$ is expressed on these vessels and antagonists of $\alpha v \beta 3$ and $\alpha v \beta 5$ may disrupt this stage of neovascularization $(23,24)$.

Osteoporosis is a disease of progressive bone loss, and reflects an imbalance between the activity of osteoclasts, the cells responsible for resorbing bone, and osteoblasts, which lay down bone matrix. Osteoclast adhesion to matrix during bone resorption has been shown to be facilitated by $\alpha v \beta 3$ (25-27). Specifically, intravenous administration of SC56631, a synthetic mimetic of the Arg-GlyAsp (RGD) sequence recognized by $\alpha v \beta 3$ and $\alpha v \beta 5$, has been shown to prevent the loss of trabecular bone sustained by rats within six weeks of oophorectomy (6).

Although antibody and peptide blocking experiments are valuable for assessing the potential roles of receptors, such studies have limitations and, in particular, are not well-suited to studying the roles of $\alpha v \beta 3$ in development. We have generated $\beta 3$-integrin-deficient mice to further our knowledge of the developmental, physiological, and pathological roles of $\beta 3$-integrins. We report that (a) $\beta 3$-deficient mice represent a good model for human Glanzmann thrombasthenia, having virtually all the cardinal characteristics of the human disease, including gastrointestinal (GI) and cutaneous hemorrhage, prolonged bleeding times, abnormal platelet aggregation and clot retraction; $(b)$ the mortality rates of the $\beta 3$-deficient mice are increased, not only due to hemorrhage, but also to placental defects in the $\beta 3$-null mothers; and $(c) \beta 3$-integrin deficiency does not prevent retinal neovascularization in seven-day-old mice.

\section{Methods}

Antibodies and matrix proteins. Rabbit antisera against the cytoplasmic domains of human $\alpha 5, \beta 1$ and chicken $\alpha 3 \mathrm{~A}$ integrin subunits were prepared as described (28-30). Rabbit antiserum against the $\alpha \mathrm{v}$-integrin subunit cytoplasmic domain was purchased from Chemicon International (Temecula, California, USA). Rabbit antiserum to $\alpha \mathrm{IIb}$ (antibody 59) was prepared by subcutaneous injections of cytoplasmic tail peptides. Rabbit antiserum to $\beta 5$ was generously provided by Martin Hemler (Dana Farber Cancer Institute, Boston, Massachusetts, USA). Rat anti-mouse $\alpha 6$ extracellular domain-specific monoclonal ant-body GoH3 was from Immunotech (Westbrook, Maine, USA) and monoclonalbiotin-labeled hamster-anti-mouse- $\beta 3$ integrin (PharMingen, San Diego, California, USA) was used for immunoprecipitation and immunofluorescence. All secondary antibodies were obtained from BioSource International (Camarillo, California, USA). Rat fibronectin and human vitronectin were obtained from Gibco BRL (Grand Island, New York, USA). Dextran-FITC (2 million) was purchased from Sigma (St. Louis, Missouri, USA).

Construction of the targeting vector. Genomic DNA clones, encompassing the $\beta 3$ exon I and exon II, were isolated from a 129Sv mouse genomic DNA library in lambdaFIXII (Stratagene, La Jolla, California, USA). Plaques were screened by hybridization with a ${ }^{32} \mathrm{P}$-labeled, PCR-amplified probe from nucleotides 1 through 165 of the mouse osteoclast $\beta 3$ cDNA (Genbank accession No. AF026509) as described (McHugh K.P. et al., manuscript in preparation). A ClaI-SaII genomic DNA fragment containing a $2.5-\mathrm{kb} 5^{\prime}$ of exon I and a $3.5-\mathrm{kb} 3^{\prime}$ of exon I was subcloned in pBluescript. The 1.7-kb EcoRI-HindIII PGKneo fragment (from $\mathrm{pKJ}-1$ ) was used to replace a HindIII genomic fragment containing exons I and II, with the addition of a HindIII/EcoRI linker (New England Biolabs, Beverly, Massachusetts, USA). The resulting construct was excised and inserted between 2 PGK-TK cassettes in the vector SK+-2TK.

Growth, transfection, and selection of targeted clones. 129Sv D3 embryonic stem (ES) cells were grown as described in $(31,32)$. 
Cells were transfected by electroporation $\left(2.5 \times 10^{7} \mathrm{ES}\right.$ cells with $25 \mu \mathrm{g}$ of linearized DNA), followed by culture and selection in the presence of G418 (200 $\mu \mathrm{g} / \mathrm{ml}$ of active drug) and gancyclovir (2 $\mu \mathrm{g} / \mathrm{ml}$; Syntex Chemicals/Roche Laboratories, Nutley, New Jersey, USA). Six to 7 days after transfection, $\sim 350$ independent colonies were isolated and expanded; half of each clone was frozen and half grown for DNA extraction and analysis. DNA was analysed by Southern blot analysis using a combination of two probes (A and B) and three restriction digests (EcoRI, BstEIII, and NcoI, Fig. 1). ES cells harboring the desired targeting events were injected into C57BL/6Ntac mouse blastocysts which were then transferred into pseudopregnant mice. After breeding, genotypes of mice were identified by PCR.

PCR analysis. Three-primer PCR was carried out for genotyping tail DNA from offspring. Common forward primer $1\left(5^{\prime}\right.$ CTTAGACACCTGCTACGGGC 3') lay 5' of the pgk-neo cassette; reverse primer 2 (5' CACGAGACTAGTGAGACGTG 3') was neo-specific and reverse primer 3 (5' CCTGCCTGAGGCTGAGTG 3') was wild-type-specific (see Fig. 1a). PCR products were $538 \mathrm{bp}$ (mutant) and $446 \mathrm{bp}$ (wild-type) (Fig. 1).

Blood collection. Mice were anesthetized with methoxyflurane or Avertin. For survival experiments, blood was collected by hepinarized capillary puncture of the retroorbital venous plexus into a tube containing 0.1 volume of $0.13 \mathrm{M}$ sodium citrate anticoagulant or $5 \mu \mathrm{l}$ of $0.5 \mathrm{M}$ EDTA, pH 8.0. For terminal experiments, mice were sacrificed by $\mathrm{CO}_{2}$ narcosis, and approximately $1 \mathrm{ml}$ of blood collected by puncture of the heart using a 1-ml syringe precoated with $0.1 \mathrm{ml}$ of $0.13 \mathrm{M}$ sodium citrate anticoagulant.

Platelet preparation. Platelets were separated from whole blood by sequential centrifugation (33). The resulting platelet-rich plas$\mathrm{ma} /$ platelet-rich buffer (PRP/PRB) mixture was used for platelet aggregation, clot retraction, and flow cytometry studies. In some experiments, platelets from two to three animals were pooled. Platelet lysates were prepared as described previously (34).

SDS-PAGE. SDS-PAGE was performed as described (35) using a $4 \%$ stacking gel and a $7.5 \%$ running gel. Gels were stained with Coomassie blue and destained in a $25 \%$ methanol-10\% acetic acid mixture.

Platelet aggregation. Aggregation of platelets in PRP/PRB was studied turbidimetrically using a two channel optical aggregometer (Chrono-Log Corp., Havertown, Pennsylvania, USA). PRP/PRB was adjusted to 140,000 platelets/ $\mu 1$ with modified Tyrode's buffer, $\mathrm{pH} 7.4$, and then $250 \mu \mathrm{PRP} / \mathrm{PRB}$ were placed in an aggregometer cuvette and warmed to $37^{\circ} \mathrm{C}$ with stirring. Aggregation was initiated by adding $5 \mu$ l of ADP to obtain final concentrations of 2,10 , or $20 \mu \mathrm{M}$ ADP. Other agonists included human thrombin at $0.1,0.5$, and $1 \mathrm{U} / \mathrm{ml}$ (ERL, South Bend, Indiana,USA), PMA at $1 \mu \mathrm{M}$ and $10 \mu \mathrm{M}$ (Sigma) and arachidonic acid at $1 \mathrm{mM}$ (Chrono-Log).

Clot retraction assays. Clot retraction was performed by two methods: (a) $0.75 \mathrm{ml} 0.053 \mathrm{M} \mathrm{Na}_{2} \mathrm{HPO}_{4}, 0.012 \mathrm{M} \mathrm{KH}_{2} \mathrm{PO}_{4}, \mathrm{pH}$ 7.4; $0.2 \mathrm{ml} \mathrm{PRP/PRB;} 5 \mu \mathrm{l}$ of $\beta 3$-null mice erythrocytes (to enhance the contrast of the clot for photography); and $50 \mu \mathrm{l}$ purified human thrombin $(50 \mathrm{U} / \mathrm{ml})$ were added to a $12-\times 75-\mathrm{mm}$ glass test tube. A glass rod was placed upright in the test tube and the test tube was placed at $37^{\circ} \mathrm{C}$ for $1 \mathrm{~h}$. (b) $200 \mu \mathrm{lRP} / \mathrm{PRB}$ was added to a siliconized aggregometer cuvette, $80 \mu \mathrm{l}$ of $50 \mathrm{mM}$ $\mathrm{CaCl}_{2}$ was added, and the sample mixed. A wooden stick was placed approximately $2 \mathrm{~mm}$ beneath the meniscus and held in place with parafilm. The cuvettes were incubated for $1 \mathrm{~h}$ at $37^{\circ} \mathrm{C}$.

Flow cytometry. PRP/PRB was diluted with modified Tyrode's buffer incubated with FITC-labeled hamster-anti-mouse-GPIIIa (PharMingen, San Diego, California, USA) at a final concentration of $28 \mu \mathrm{g} / \mathrm{ml} \mathrm{IgG}$. Nonspecific binding was determined by blocking the $\beta 3$ sites by preincubating the platelets with $188 \mu \mathrm{g} / \mathrm{ml}$ of unlabeled hamster anti-mouse $\beta 3$ antibody. Nonspecific signal was determined using an FITC-labeled hamster anti-TNP antibody (PharMingen) at $28 \mu \mathrm{g} / \mathrm{ml}$. Samples were analyzed by flow cytometry (FACScan; Becton Dickinson, Bedford, Massachusetts, USA).

Blood counts. Whole blood was collected by retroorbital bleed and $200 \mu \mathrm{l}$ volumes analysed on a Hemavet (CBC Tech, Oxford, Connecticut, USA) Coulter Counter.

Bleeding time assays. The bleeding time was performed as described (36) by immersing the severed tip of the tail in $0.9 \%$ isotonic saline at $37^{\circ} \mathrm{C}$. The bleeding time was defined as the time required for the stream of bleeding to cease. All experiments were stopped at $10 \mathrm{~min}$ by cauterizing the tail.

Shwartzman reaction. A local reaction induced by LPS and TNF $\alpha$ was carried out as described $(37,38)$. A priming dose of Escherichia coli lipopolysaccharide (LPS; Difco Labs, Detroit, Michigan, USA; $100 \mu \mathrm{g}$ in $100 \mu \mathrm{l}$ of sterile PBS) was injected subcutaneously using a 27 -gauge needle. Mouse recombinant TNF $\alpha(0.3 \mu \mathrm{g}$ in $100 \mu \mathrm{l}$ PBS; Genzyme, Cambridge, Massachusetts) was injected subcutaneously at the same site 20-24 h later. Lesions were observed 24 hours after the second injection.

Preparation of tissue for histology. Animals were sacrificed by $\mathrm{CO}_{2}$ narcosis and limbs removed. Tissue for paraffin embedding was fixed in $4 \%$ formaldehyde for $24 \mathrm{~h}$ at room temperature followed by immersion in 70\% ethanol. Microscopy was carried out on a Zeiss Axiophot microscope.

Surface iodination and immunoprecipitation of integrins. Monolayers of MEFs prepared from E17 embryos as described (39) that had been passaged twice or platelets were surface-labeled with $0.5 \mu \mathrm{Ci} / 10 \mathrm{~cm}$ plate of $\mathrm{Na}\left[{ }^{125} \mathrm{I}\right]$ (DuPont NEN Research Products, Boston, Massachusetts, USA) using lactoperoxidase

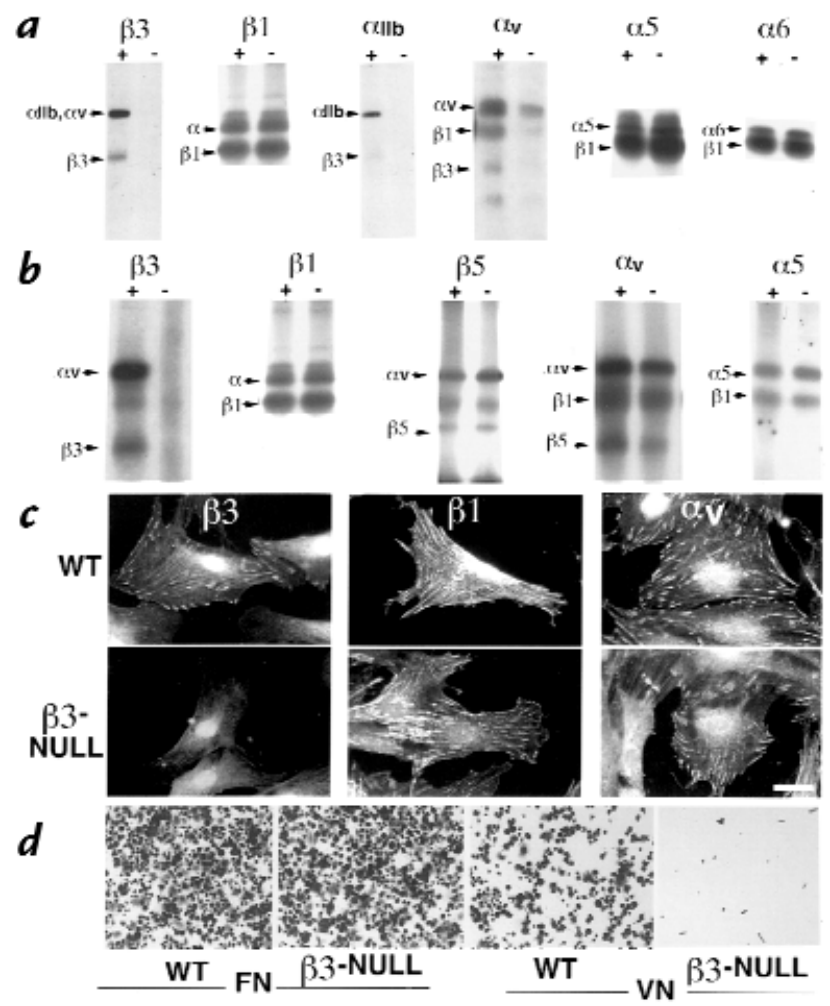

Figure 2

Integrin profiles of cells isolated from the $\beta 3$-null mice. (a) Surface iodination of platelets and immunoprecipitation of integrins $\beta 3, \beta 1, \alpha \mathrm{llb}, \alpha \mathrm{v}$, $\alpha 5$ and $\alpha 6$ from wild-type (+) and $\beta 3$-null (-) mice. (b) Surface iodination of mouse embryo fibroblasts (MEFs) and immunoprecipitation of $\beta 3, \beta 1$, $\beta 5$, $\alpha v$, and $\alpha 5$. (c) Immunofluorescence staining of $\beta 3, \beta 1$, and $\alpha v$-integrins on wild-type and $\beta 3$-null MEFs. (d) Adhesion assays with wild-type and $\beta 3$-null MEFs on fibronectin and vitronectin. $\operatorname{Bar}(c), 15 \mu \mathrm{m}$. 

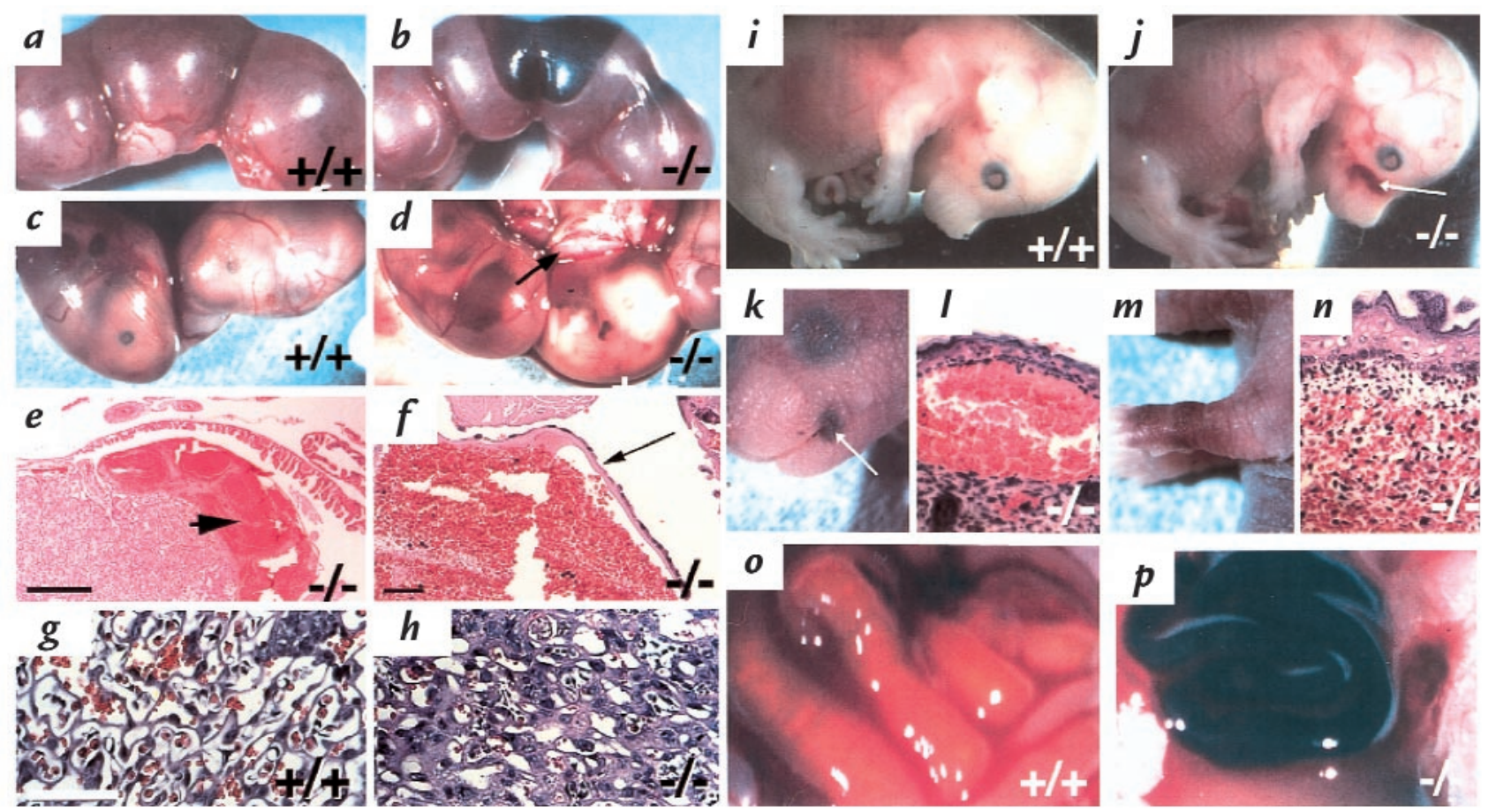

Figure 3

Survival of $\beta 3$-null mice is compromised. Uteri from typical wild-type ( $\boldsymbol{a})$ and $\beta 3$-null (b) females that had been bred to $\beta 3$-null or wild-type males, respectively. Dark patches in (b) indicate bleeding in $\beta 3$-null uterus. ( $\boldsymbol{c}$ and $\boldsymbol{d}$ ) Heterozygous E16 embryos in utero, in wild-type (c) or $\beta 3$-null $(d)$ mothers. Some pups die in $\beta 3$-null mothers in utero, appearing pale, small and associated with a pale placenta (arrow). (e, $\boldsymbol{f}$ and h) $\mathrm{H} \& \mathrm{E}$ stained sections of placentae from $\beta 3$-null females mated with wild-type males. H\&E stained section of placenta from wild-type female mated with a $\beta 3$-null male $(\boldsymbol{g})$. Arrowhead indicates severe hemorrhage observed within the labyrinth $(e)$ and under the Reichert's membrane $(f)$. $(g)$ Labyrinth of wild-type placenta; $(h)$ Labyrinth of $\beta 3$-null placenta where cell layers appear thick; this occurs in $\sim 25 \%$ of $\beta 3$-null placentae. ( $\boldsymbol{i}$ and $\boldsymbol{j}$ ) E16 embryos, wild-type $(i)$ and $\beta 3$-null $(j)$. Note hemorrhage in $\beta 3$-null muzzle. Arrow indicates hemorrhage in the skin. $(\boldsymbol{k}$, $\boldsymbol{I}, \boldsymbol{m}$, and $\boldsymbol{n})$ After birth, some $\beta 3$-null mice suffer hemorrhage in the skin. Petechiae around the mouth of a 1-day-old $\beta 3$-null pup ( $k$ ) and H\&Estained section of this region indicating bleeding under the epidermis $(I)$. Purpura on the forelimb of a 1-day-old $\beta 3$-null pup $(m)$ and $\mathrm{H} \& \mathrm{E}-$ stained section of this region indicating bleeding within the dermis $(n)$. $(\boldsymbol{o}$ and $\boldsymbol{p})$ Gut from newborn pups. Wild-type $(\boldsymbol{o})$ and $\beta 3$-null pup with acute Gl hemorrhage $(p)$. Bar $(e), 400 \mu \mathrm{m}(f), 50 \mu \mathrm{m}$, and $(g), 70 \mu \mathrm{m}$.

and glucose oxidase. To compare the relative amounts of each integrin between wild-type and $\beta 3$-null cells, $5 \times 10^{5}$ TCA-precipitable counts were immunoprecipitated with each anti-integrin antibody as described (28). Non-reducing SDS-PAGE was performed using $5 \%$ acrylamide and a 3\% stacking gel (35).

Immunofluorescence microscopy. MEFs grown on glass coverslips were fixed in $4 \%$ paraformaldehyde in PBS for $20 \mathrm{~min}$, permeablized in $0.1 \%$ NP40 in PBS for 10 minutes at room temperature, and blocked with $0.1 \%$ BSA, $0.2 \%$ Triton X-100, $0.1 \%$ glycine in PBS for $1 \mathrm{~h}$ before 1 -h incubation with primary antibodies. Cells were washed in PBS and incubated with secondary antibodies at a 1:200 dilution in blocking solution. Finally, cells were washed in PBS, and then distilled water and mounted in Gelvatol (Monsanto, St. Louis, Missouri, USA) containing the anti-bleaching agent, DABCO (Sigma,USA).

Perfusion of 5- and 7-day-old pups with $1 \mathrm{ml}$ of $50 \mathrm{mg} / \mathrm{ml}$ Dextran-FITC and preparation of retinal flat mounts were carried out as described (40).

Adhesion assays. 96-well bacteriological plates (Nunc, Rochester, New York, USA) were coated with $10 \mathrm{ug} / \mathrm{ml}$ of fibronectin or vitronectin in PBS overnight at $4^{\circ} \mathrm{C}$. The plates were washed briefly and then blocked in $10 \mathrm{mg} / \mathrm{ml} \mathrm{BSA}$ in PBS for $2 \mathrm{~h}$ at $37^{\circ} \mathrm{C}$. Cells $\left(5 \times 10^{4}\right)$ in $100 \mu \mathrm{l}$ of serum-free medium containing $25 \mu \mathrm{M}$ cycloheximide were plated per well for $1 \mathrm{~h}$ at $37^{\circ} \mathrm{C}$. Adherent cells were fixed and stained in $1 \%$ crystal violet in $\mathrm{H}_{2} \mathrm{O}$ and observed.

\section{Results}

Targeted disruption of the $\beta 3$-integrin gene in ES cells by homologous recombination. The $\beta 3$ integrin gene was inactivated in D3 ES cells by homologous recombination using a targeting vector which contained a pgk-neomycin-resistance (pgk-neo) cassette for positive selection and two thymidine kinase (pgk-TK) cassettes to select against random insertions (negative selection) (See Fig. 1a). Homologous recombination replaced a $1.4-\mathrm{kb}$ region of the wild-type allele containing exons I and II by the 1.7kb pgk-neo cassette. After electroporation, double-resistant clones were isolated and screened by Southern blotting using two probes and three restriction digests (Fig. $1, a$ and $b$ ). Three clones that had undergone correct homologous recombination were isolated (Fig. 1b). All three clones were injected into C57BL/6 blastocysts and transferred into pseudopregnant females; when crossed with C57BL/ 6 females, chimeras from two clones gave germline transmission and the resulting heterozygotes were intercrossed. Animals were tested for their genotype by PCR analysis using a three-primer technique (see Fig. $1 a$ for primer locations, and Fig. 1c). As shown, viable 
homozygous mutant mice were obtained.

Integrin profiles of cells isolated from $\beta 3$-null mice. The integrin profiles of wild-type and $\beta 3$-null platelets and MEFs were compared. FACS analysis of platelets showed that there was approximately half as much $\beta 3$-integrin on the surfaces of $\beta 3$-heterozygous platelets as on wild-type platelets and that the $\beta 3$-null platelets had undetectable levels of $\beta 3$-integrin (data not shown). Surface iodinations and immunoprecipitations of platelets and MEFs isolated from wild-type and $\beta 3$-null mice showed that $\beta 3$-null cells had undetectable levels of $\alpha \mathrm{v} \beta 3$ and $\alpha \operatorname{IIb} \beta 3$ integrins and all other integrins tested remained normal compared with wild-type controls. Notice that in the $\beta 3$ deficient cells, $\alpha v \beta 1$ and $\alpha v \beta 5$ persisted and did not show evidence of upregulation in expression in compensation for the absence of $\beta 3$ (Fig. 2, $a$ and $b$ ).

In order to examine the focal contact distribution of the integrins in the $\beta 3$-null MEFs immunofluorescence was carried out using antibodies directed against various integrins including $\beta 3, \beta 1$ and $\alpha v$. Apart from the absence of detectable $\beta 3$-integrin in the $\beta 3$-null MEFs, there were no

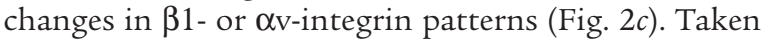
together, the FACS analysis, immunoprecipitations and immunofluorescence assays indicated that, apart from the loss of the $\beta 3$-subunit, there were no major changes in the other integrins expressed by platelets or MEFs.

$\alpha v \beta 3$ integrin is a major receptor for vitronectin in MEFs. To test whether the loss of $\beta 3$-integrins had any effect on the roles of the other integrins expressed by these cells, adhesion assays were performed on fibronectin and vitronectin. $\beta 3$-null MEFs had negligible ability to bind to vitronectin when compared with wild-type controls, whereas adhesion to fibronectin was not affected (Fig. $2 d$ ).

Compromised survival of embryos in $\beta 3$-null mothers as a result of placental defects and intrauterine hemorrhage. Although viable and fertile $\beta 3$-null mice were obtained, the litter sizes were reduced significantly $(4.6 \pm 2.9 \beta 3$ null versus $8.6 \pm 2.8$ wild-type pups per litter at weaning; $n=49$ and 29, respectively; $P<0.005$ ). The survival of $\beta 3$ null mice is compromised at various stages of development. Prenatally, $\beta 3$-null mothers suffered intrauterine hemorrhage and placentation defects. When $\beta 3$-null females were mated with wild-type males and wild-type females were mated with $\beta 3$-null males, the average number of embryos (all heterozygotes) per litter between $\mathrm{E} 14$ and $\mathrm{E} 17$ was the same $(8.5 \pm 2.8$ versus $8.6 \pm 2.2 n=$ 14 and 5 , respectively). However, $9.5 \%$ of the embryos carried by $\beta 3$-null mothers were found dead in utero (Fig. $3 d$ ) whereas fewer than $1 \%$ of embryos were found dead in utero in wild-type females (Fig. 3c). The heterozygous embryos found dead in utero in the $\beta 3$-null females did not show signs of hemorrhage; however, hemorrhage was evident in $77 \%$ of $\beta 3$-null uteri (Fig. 3b). The site of hemorrhage was within the labyrinth of the placenta, with blood pools often "ballooning" under the Reichert's membrane (Fig. 3, $e$ and f). Intrauterine bleeding was not observed in wild-type or heterozygous females (Fig. 3, $a$ and $c$ ). Thus, one cause of death in pregnant $\beta 3$-null females was intrauterine bleeding.

In addition to intrauterine bleeding, $\beta 3$-null mothers also showed evidence of thickened cell layers in the labyrinth layer in approximately $25 \%$ of placentae exam- ined (Fig. 3, $g$ and $h$ ). Such placentae were associated with dead embryos. Within these affected placentae the space between endothelial layers was reduced, there was evidence of increased necrosis, and, sometimes, invasion of the labyrinthine part of the placenta with trophoblastic cells. All these characteristics presumably resulted in restricted blood flow within the placenta, thus giving rise to a pale appearance of the placentae (Fig. 3d).

Apart from the $\beta 3$-null maternal defects that caused reduced survival of embryos, some $\beta 3$-null embryos also displayed hemorrhage in the skin and appeared anemic (Fig. 3, $i$ and $j$ ). The numbers of embryos found in utero in $\beta 3$-null $\times$ null, het $\times$ het or wild-type $\times$ wild-type crosses were not significantly different $(7.2 \pm 2.4,9.0 \pm 1.8$ and $7.7 \pm 2.8$ [ $n=7-12]$, respectively). However, $13 \%$ of $\beta 3$-null embryos from $\beta 3$ null crosses were found dead in utero compared with only $1 \%$ from heterozygous or wild-type
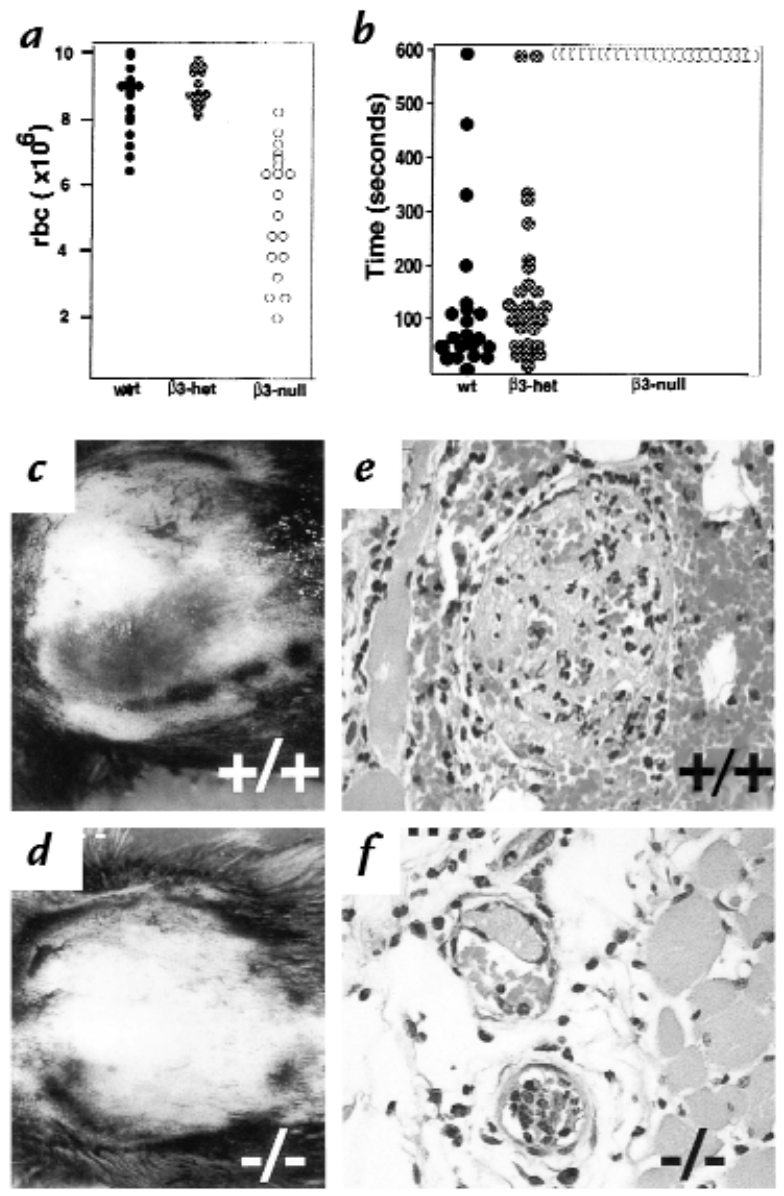

\section{Figure 4}

Blood cell counts and Bleeding assays. (a) Red blood cell counts are reduced in randomly selected 8-12-week-old $\beta 3$-null mice. Means and standard errors of the means for wild-type, $\beta 3$-het and $\beta 3$-null animals are as follows: $8.9 \pm 0.15,9.0 \pm 0.16$ and $6.0 \pm 0.3\left(\times 10^{6} / \mathrm{mm}^{3}\right)$, a significant difference $(P<0.005)$ between $\beta 3$-null and others. $(\boldsymbol{b})$ Tail bleeding times. $\beta 3$-null mice all show bleeding times of at least $10 \mathrm{~min}$ (at which time bleeding was stopped by cauterization). This was significantly greater than that for either wild-type or $\beta 3$-heterozygous mice $(P<$ $0.005)$. $(c-f)$ Localized Shwartzman reactions. Gross hemorrhage in wildtype $(c)$, but not $\beta 3$-null $(d)$ skin after LPS and TNF $\alpha$ challenge. Histology of blood vessels in the skin after LPS and TNF $\alpha$ challenge in wild-type dermis $(e)$ and $\beta 3$-null dermis $(f)$. 


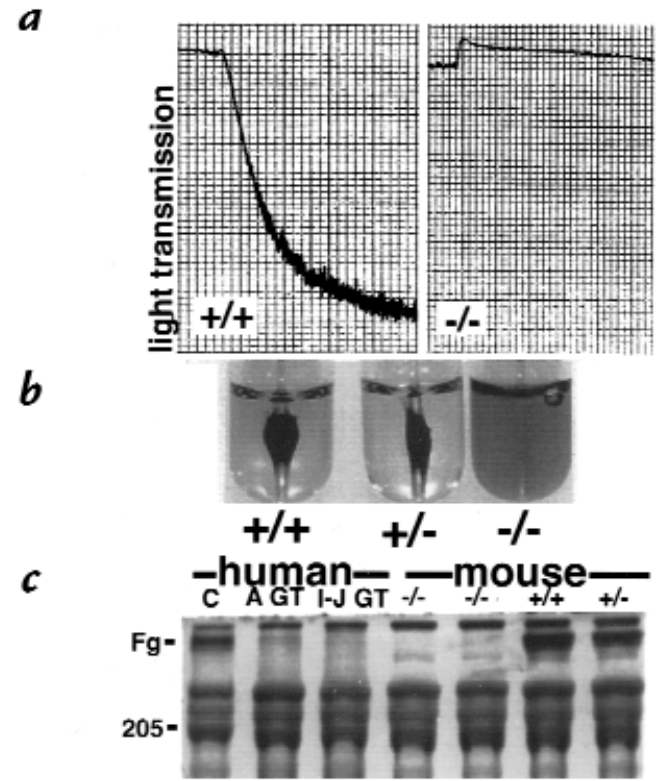

\section{Figure 5}

Functional assays of platelets in vitro show that the $\beta 3$-null platelets do not aggregate $(\boldsymbol{a})$, have reduced clot retraction $(\boldsymbol{b})$, and greatly reduced fibrinogen uptake $(\boldsymbol{c})$. A GT is a platelet lysate from an Arab patient with Glanzmann thrombasthenia, who has a defect in GPIIb and I-J GT is a platelet lysate from an Iraqi-Jewish GT patient with a defect in $\beta 3$ (GPIIla).

crosses. These data indicate that $\beta 3$-integrin deficiency caused prenatal loss of embryos both due to fetal hemorrhage and to abnormalities in $\beta 3$-null placentae.

Spontaneous hemorrhage in $\beta 3$-null mice further reduces their survival. In order to examine the survival of $\beta 3$-null animals after birth, the numbers of pups per litter from heterozygous or $\beta 3$-null crosses were monitored. At three days postpartum, there were significantly fewer pups per $\beta 3$-null litter than in wild-type litters. Up to three weeks of age there was a further $18 \%$ loss of $\beta 3$-null pups. The loss of $\beta 3$-null pups was due to hemorrhage either in the skin, in petechiae (Fig. 3, $k$ and I), in purpura (Fig. 3, $m$ and $n$ ), or in the GI tract (Fig. 3p).

Gastrointestinal bleeding in randomly selected adults (3 weeks to 8 months in age) was assessed in two ways: (a) by macroscopic observation during necropsy and $(b)$ using a Hemoccult stool test. Upon necropsy, $12 \%$ of randomly selected 3-7-week-old $\beta 3$-null mice showed evidence of blood in the gut. The Hemoccult stool test was a more sensitive assay for GI bleeding and $60 \%$ of 3-7-week-old $\beta 3$ null animals were positive by this test. It was commonly found that the stomach and intestines of animals in crisis appeared black and upon dissection were often filled with a gritty black mash, similar to coffee grounds. This material had the typical appearance of partially digested blood that filled the lumen of the gut. GI bleeding was also commonly associated with enlargement of the spleen. The GI bleeding was progressive as the $\beta 3$-null mice aged. By 8 months of age, $45 \%$ displayed gross GI bleeding and $95 \%$ were positive by Hemoccult tests. The splenomegaly appeared likely to be a secondary effect of chronic blood loss since histology showed extramedullary hematopoiesis in enlarged spleens (Fig. 6). None of the wild-type or $\beta 3$ - heterozygous animals tested showed GI bleeding.

In addition to the chronic bleeding, some $\beta 3$-null animals suffered acute blood loss and would enter sudden crisis. $\beta 3$-null animals were found in crisis or dead. Of 400 animals between 3 and 7 weeks of age, 23 were found dead and 10 were found in crisis. Of 350 animals between 8 weeks and 13 months of age, 55 were found dead and 37 in crisis. All animals in crisis had various combinations of GI bleeding, enlarged spleens, anemia, and ulcerative dermatitis. In contrast, only a few of the oldest wild-type or heterozygous mice developed ulcerative dermatitis and none showed hemorrhage.

Blood counts from $\beta 3$-null mice indicate a significant reduction in red blood cells, hemoglobin and hematocrit. Hematological profiles from randomly selected, 8-12-week-old wild-type, $\beta 3$-heterozygous, and $\beta 3$-null mice showed no significant differences in white blood cell counts or differential counts (Table 1). Although there was a trend toward decreased platelet numbers in the $\beta 3$-null mice, this was not significantly different from the wild-type mice. However, red blood cell counts (Fig. 4a), hemoglobin, and hematocrits were all reduced in the $\beta 3$-null mice. There were no significant differences between wildtype and $\beta 3$-heterozygous mice. The decreased red blood cell count was most likely the result of chronic bleeding that the $\beta 3$-null animals suffered; reticulocyte counts were also extremely high (Table 1), indicating an appropriate erythropoietic response to the blood loss.

$\beta 3$-null mice have greatly prolonged bleeding times and reduced thrombus formation. To examine whether the absence of $\beta 3$ integrins affects hemostasis in the deficient mice, we measured the bleeding times of the $\beta 3$-null, heterozygous and wild-type mice. Although there was no significant difference between bleeding times of wild-type and $\beta 3$-heterozygous mice (average $50-150$ seconds), all of the $\beta 3$ null mice had greatly prolonged bleeding times exceeding 600 seconds, at which time the experiment was stopped (Fig. $4 b$ ). The results clearly indicated that $\beta 3$-deficiency gave rise to greatly extended bleeding times.

We also studied the local Shwartzman-like reaction, a model of hemorrhagic vasculitis, induced by subcutaneous injection of LPS followed $24 \mathrm{~h}$ later by an injection of TNF $\alpha$ in the same place. Hemorrhagic lesions ranging from no lesion (minimum macroscopic score of 0 ) to hemorrhagic necrosis (maximum macroscopic score of 4) were observed 24 hours after the second injection. Although a wide range of hemorrhagic lesions was observed in the wild-type mice, with a mean macroscopic score of $3.03 \pm 0.35$, the $\beta 3$-null mice showed significantly lower grades of hemorrhage, with an average score of $0.74 \pm 0.28$ (Fig. $4, c$ and $d$ ). $94 \%$ of wild-type mice developed lesions as opposed to $43 \%$ of $\beta 3$-null mice. Histological analysis showed that the numbers of blood vessels containing thrombi were significantly reduced from $71 \pm$ 7.8 to $39 \pm 9 \%$ in the $\beta 3$-null mice $(P<0.005)$. The degree of hemorrhage observed in the sections ranged from no hemorrhage (hemorrhage score of 0 ) to maximal hemorrhage throughout the skin (hemorrhage score of 4); average microscopic hemorrhagic scores were $2.3 \pm 0.37$ for wild-type and $0.92 \pm 0.26$ for $\beta 3$-null (Fig. 4, $e$ and $f$ ). Although there was a tendency toward decreased neutrophil infiltration in the $\beta 3$-null mice, the difference was 

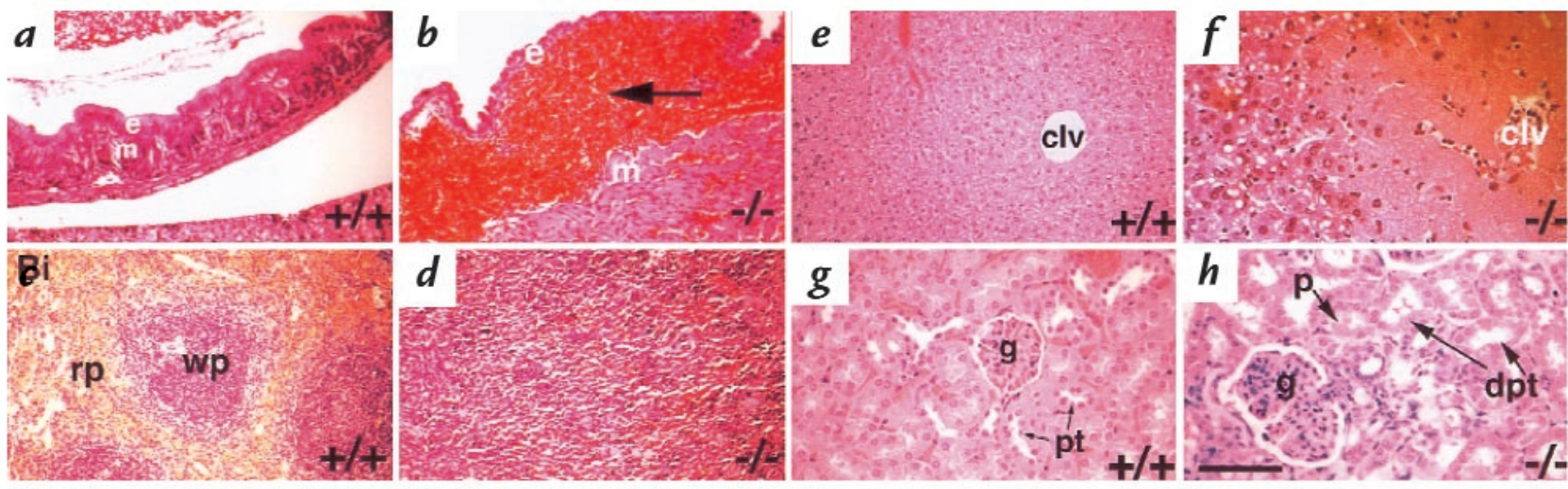

Figure 6

b3-null mice in crisis display a variety of secondary phenotypes. H\&E-stained sections from wild-type $(\boldsymbol{a}, \boldsymbol{c}, \boldsymbol{e}$, and $\boldsymbol{g})$ and from b3-null mice found in crisis $(\boldsymbol{b}, \boldsymbol{d}, \boldsymbol{f}$, and $\boldsymbol{h})$. ( $a$ and $b$ ) Gastrointestinal bleeding can be observed in the lamina propria between the stomach epithelium (e) and muscularis mucosae $(\mathrm{m}) .(c)$ White pulp (wp) and red pulp (rp) are clearly defined in wild-type spleen. Splenomegaly in anemic mice with extramedullary erythropoiesis $(d)$. Centrilobular necrosis of the b3-null liver $(f)$ is a consequence of severe anemia resulting in lack of well-oxygenated blood reaching the centrilobular vein (clv). Glomerular nephritis and resultant tubular necrosis are also secondary to anemia $(h)$. Notice the dilated proximal tubules (dpt), enlarged glomerulus (g), and proteinaceous deposits $(\mathrm{p})$ in the tubules. Normal proximal tubules are denoted, pt. Bar, $70 \mathrm{~mm}$.

not statistically significant. The decrease in hemorrhage in the Shwartzman reaction in the $\beta 3$-null mice might appear paradoxical in light of the prolonged bleeding times observed in these mice. However, the hemorrhage in the Shwartzman reaction is secondary to thrombus formation, with occlusion of vessels giving rise to vascular injury, loss of vascular integrity, and finally hemorrhage. Since the $\beta 3$-null mice do not readily form throm$\mathrm{bi}$, vascular injury is rare and hemorrhage is reduced.

In vitro assays of $\beta 3$-null platelets show many of the characteristics of Glanzmann thrombasthenic platelets. Since the $\beta 3$-null mice showed prolonged bleeding times we examined the functions of $\beta 3$-deficient platelets in vitro. ADP-induced platelet aggregation was normal in the wild-type and $\beta 3$ heterozygous platelets, but the $\beta 3$-deficient platelets did not aggregate (Fig. $5 a$ ), although they did demonstrate shape change in response to ADP showing that this process is $\beta 3$-integrin-independent. Identical results were obtained with other agonists, including human thrombin at $0.1,0.5$ and $1 \mathrm{U} / \mathrm{ml}, \mathrm{PMA}$ at $1 \mu \mathrm{M}$ and $10 \mu \mathrm{M}$ and arachidonic acid at $1 \mathrm{mM}$ (data not shown).

Clot retraction assays were performed by the addition of thrombin to platelet-rich plasma. After 1 hour at $37^{\circ} \mathrm{C}$, the thrombin-induced clots formed in wild-type and heterozygous samples retracted extensively around the glass rod (Fig. $5 b$ ). In marked contrast, the clots formed in the $\beta 3$-null samples had not retracted at all. Similar data were obtained in five separate experiments using the same method or an alternative technique in which clot formation was induced by recalcification (data not shown).

Platelet fibrinogen uptake in the $\beta 3$-null platelets was examined on Coomassie-stained gels of platelet lysates. Normal control human, wild-type and heterozygous mouse platelet lysates each contained a prominent fibrinogen band; however, fibrinogen was nearly absent from the $\beta 3$-null and Glanzmann thrombasthenic platelet lysates (Fig. 5c).

Glanzmann thrombasthenic platelets characteristically have reduced platelet aggregation, decreased clot retraction and fibrinogen uptake. Our results with the $\beta 3$-deficient platelets show that the $\beta 3$-null mice have functional defects essentially identical to those found in Glanzmann thrombasthenia.

Excessive bleeding in the $\beta 3-n u l l$ mice is manifested in various secondary phenotypes. As described earlier, a small percentage of adult $\beta 3$-null mice (3 weeks of age and older) undergo acute bleeding crises most often caused by severe GI bleeding. Histological analysis of randomly selected animals showed that those mice with GI bleeding (detected by Hemoccult reactions) all had varying degrees of splenomegaly, and liver and kidney necrosis. Those without GI bleeding did not display these phenotypes of the GI tract. Histology revealed that hemorrhage occurred between the muscle wall and epithelial lining of the gut (Fig. 6, $a$ and $b$ ) and that in the most extreme cases the
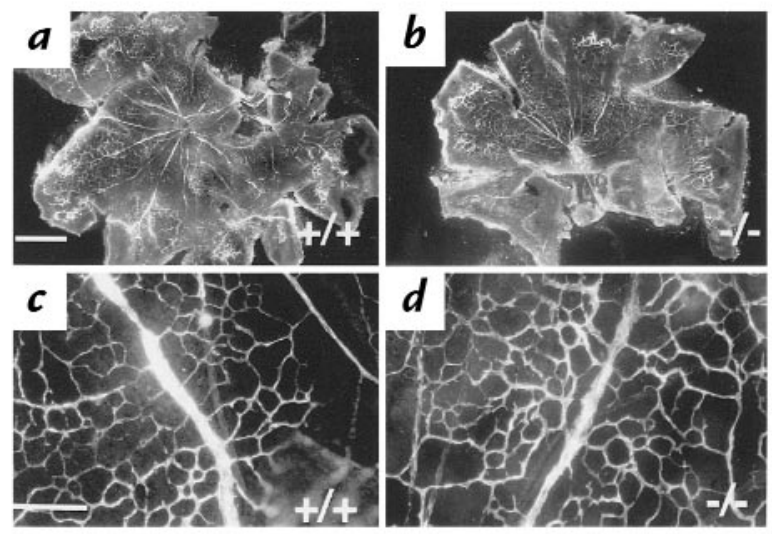

\section{Figure 7}

Neovascularization in the $\beta 3$-null developing retina is not inhibited by the absence of $\beta 3$-integrins. Blood vessels in wild-type ( $\boldsymbol{a}$ and $\boldsymbol{c}$ ) and $\beta 3$-null $(\boldsymbol{b}$ and $\boldsymbol{d}$ ) retinas were observed at $\mathrm{P} 7$. Whole flat-mount retinas at low power $(a$ and $b)$ and high-power views of branching from major blood vessels radiating from the optic disc ( $c$ and $d$ ). Bar $(a), 800 \mu \mathrm{m} ;(c), 50 \mu \mathrm{m}$. 
Table 1

Blood counts and differentials

\begin{tabular}{|c|c|c|c|}
\hline Blood counts & wild type & $\beta 3$-het & $\beta 3$-null \\
\hline White blood cells $\left(\times 10^{3} / \mathrm{mm}^{3}\right)$ & $\begin{array}{l}5.2 \pm 2.3 \\
(n=23)\end{array}$ & $\begin{array}{l}6.3 \pm 1.8 \\
(n=23)\end{array}$ & $\begin{array}{l}5.5 \pm 1.2 \\
(n=21)\end{array}$ \\
\hline Red blood cells $\left(\times 10^{6} / \mathrm{mm}^{3}\right)$ & $\begin{array}{c}8.9 \pm 0.15^{\AA} \\
(n=21)\end{array}$ & $\begin{array}{c}9.0 \pm 0.16 \\
(n=23)\end{array}$ & $\begin{array}{c}6.0 \pm 0.3^{A} \\
(n=23)\end{array}$ \\
\hline Reticulocytes (\%) & $\begin{array}{c}2.2 \pm 0.4^{\AA} \\
(n=12)\end{array}$ & $\begin{array}{l}1.8 \pm 0.2 \\
(n=14)\end{array}$ & $\begin{array}{c}31 \pm 8.5^{A} \\
(n=15)\end{array}$ \\
\hline Hemoglobin (g/dl) & $\begin{array}{c}14.5 \pm 0.14^{4} \\
(n=21)\end{array}$ & $\begin{array}{c}14.5 \pm 0.16 \\
(n=23)\end{array}$ & $\begin{array}{c}11.5 \pm 0.5^{A} \\
(n=22)\end{array}$ \\
\hline Hematocrit (\%) & $\begin{array}{c}44.0 \pm 1.2^{\mathrm{A}} \\
(n=22)\end{array}$ & $\begin{array}{c}44.4 \pm 1.1 \\
(n=23)\end{array}$ & $\begin{array}{c}35.9 \pm 1.7^{A} \\
(n=23)\end{array}$ \\
\hline Platelets $\left(\times 10^{9} / 1\right)$ & $\begin{array}{c}648 \pm 38 \\
(n=21)\end{array}$ & $\begin{array}{c}631 \pm 29 \\
(n=23)\end{array}$ & $\begin{array}{c}547 \pm 36 \\
(n=23)\end{array}$ \\
\hline Neutrophils (\%) & $\begin{array}{c}18.2 \pm 2.2 \\
(n=32)\end{array}$ & $\begin{array}{c}17.5 \pm 1.6 \\
(n=32)\end{array}$ & $\begin{array}{c}19.0 \pm 2.8 \\
(n=33)\end{array}$ \\
\hline Lymphocytes (\%) & $\begin{array}{c}76.7 \pm 2.4 \\
(n=32)\end{array}$ & $\begin{array}{c}78.6 \pm 1.6 \\
(n=32)\end{array}$ & $\begin{array}{c}77.5 \pm 2.4 \\
(n=34)\end{array}$ \\
\hline Monocytes (\%) & $\begin{array}{c}2.5 \pm 0.5 \\
(n=32)\end{array}$ & $\begin{array}{c}2.1 \pm 0.3 \\
(n=33)\end{array}$ & $\begin{array}{c}2.6 \pm 0.3 \\
(n=34)\end{array}$ \\
\hline Eosinophils (\%) & $\begin{array}{c}2.5 \pm 0.4 \\
(n=33)\end{array}$ & $\begin{array}{c}1.75 \pm 0.3 \\
(n=32)\end{array}$ & $\begin{array}{c}1.4 \pm 0.3 \\
(n=34)\end{array}$ \\
\hline
\end{tabular}

There was no significant difference between numbers of wild-type and null white blood cells, platelets, neutrophils, lymphocytes, monocytes, or eosinophils. ASignificant differences of $P<0.0005 ; n=$ number of samples tested. Values are given as the mean $\pm S E M$.

epithelial lining ruptured and blood filled the lumen. The resulting anemia observed in the $\beta 3$-null mice manifested itself in: splenomegaly with elevated erythropoiesis (Fig. 6, $c$ and d); centrilobular necrosis of the liver (Fig. 6, $e$ and $f$ ); and kidney defects with enlarged glomeruli and dilated and necrotic proximal tubules containing proteinaceous deposits (Fig. 6, $g$ and $h$ ). In the population of mice in crisis the spleen sizes varied between 2 and 10 times that of normal spleens.

Neovascularization during retinal development is not dependent on $\beta 3$-integrins in mice. Newborn mice develop retinal blood vessels during the first two weeks postnatally and it has been reported that this process is inhibited by peptides that block $\alpha v \beta 3$ integrin function (23). To investigate whether this type of neovascularization is affected in the $\beta 3$-null mice, we visualized retinal vessels by the perfusion of FITC-conjugated dextran. The patterns of neovascularization in P7 (postnatal day 7) retinas isolated from wild-type or $\beta 3$-null mice showed no obvious differences in either the distance of vessel growth from the optic nerve head or in the basic pattern of branching (Fig. 7). Similar results were obtained from P5 animals (data not shown).

\section{Discussion}

We have generated $\beta 3$-null mice to characterize the functions of $\beta 3$-integrins. These mice are viable and fertile, but have reduced survival due, first, to abnormalities in the maternal component of the $\beta 3$-null placenta and, second, to excessive GI bleeding at various stages throughout life.

B3-Null mice as a model for Glanzmann thrombasthenia. Glanzmann thrombasthenia is a rare hemorrhagic disorder characterized by prolonged bleeding time, normal platelet count, and absent macroscopic platelet aggregation. The defect in platelet function responsible for Glanzmann thrombasthenia is the inability of thrombasthenic platelets to aggregate due to deficiencies or dysfunctions in $\alpha \operatorname{IIb} \beta 3$ integrin $(15,41,42)$. The $\beta 3$-integrinnull mice display many features of Glanzmann thrombasthenia including greatly extended bleeding times and thus provide a good model to study the roles of $\beta 3$-integrins in this human disease. Although valuable work has been carried out on platelets harvested from Glanzmann thrombasthenic patients, the disease is relatively rare, and only limited quantities of blood are available for experimental analysis. Major advantages of having $\beta 3$-null mice are the potentially unlimited quantity of blood now available for experimentation and the availability of a model to test therapeutic reagents to treat Glanzmann thrombasthenia.

Essentially all the clinical features displayed by Glanzmann thrombasthenic patients (reviewed in 14) are also found in $\beta 3$-knockout mice. For example, purpura and petechiae can be present immediately after birth in Glanzmann thrombasthenic babies. We observed both purpura and petechiae in newborn $\beta 3$-knockout pups, and in adult animals purpura would occasionally progress to the development of intradermal hematomas (Fig. 3). GI bleeding has been observed in up to $49 \%$ of Glanzmann thrombasthenic patients. The bleeding is usually intermittent and the bleeding site difficult to identify. Our observations in $\beta 3$-knockout mice have revealed that up to $95 \%$ of the older $\beta 3$-null mice display GI bleeding, and we have identified one potential bleeding site as the lamina propria between the stomach epithelium and the muscularis mucosae (Fig. 6). In addition to this, the severe bleeding in the $\beta 3$-null mice also results in secondary effects of anemia, including splenomegaly, centrilobular necrosis in the liver, glomerular and tubular nephritis. Such secondary features are not reported to be common in Glanzmann thrombasthenic patients, probably because these patients are treated before they suffer equivalently massive blood loss.

Patients with Glanzmann thrombasthenia have not been reported to bleed excessively during pregnancy, but immediate postpartum hemorrhage is very common unless platelet transfusions are administered. The $\beta 3$-null mice display hemorrhage within the placenta, under the Reichert's membrane, and this can be observed in $77 \%$ of $\beta 3$-null mothers (Fig. 3). Moreover, the intrauterine hemorrhage leads to early mortality of approximately $10 \%$ of the embryos. It would be interesting to investigate whether Glanzmann thrombasthenic patients also suffer from reduced fecundity resulting from such intrauterine hemorrhage, but a large number of observations would be required to detect such a defect. Interestingly, despite the uterine hemorrhage, only a small proportion of $\beta 3$ null mice die because of postpartum hemorrhage. 
Platelets from Glanzmann thrombasthenic patients display three major laboratory characteristics: decreased or absent aggregation, reduced or absent clot retraction, and reduced or absent fibrinogen uptake. All of these characteristics were examined in the platelets from $\beta 3$ null mice and were shown to be identical to those of $\beta 3$ null Iraqi-Jewish Glanzmann thrombasthenic platelets (Fig. 5). There was no evidence for upregulation of other integrins in the platelets or MEFs isolated from the $\beta 3$ knockout mice (Fig. 2), although we cannot rule out any overlapping roles or effects of other molecules.

B3-integrin deficiency reduces Shwartzman reaction responses. Apart from the prolonged bleeding times exhibited by the $\beta 3$-knockout mice, we also showed that $\beta 3$-deficiency reduces thrombus formation and protects against hemorrhage induced by injection of LPS and TNF $\alpha$ in the local Shwartzman reaction (Fig. 4)(37, 38). In this reaction microthrombi, composed of platelets, neutrophils and fibrin, occlude the capillaries and venules. The microthrombi together with cytokines cause endothelial damage that can result in vessel damage, leakage and finally hemorrhage. It is interesting to compare the results from the $\beta 3$-null mice with Shwartzman reaction results from von Willebrand factor knockout mice, in which thrombus formation was reduced but hemorrhage was increased (43; and Wagner, D., personal communication). This implies that not only is platelet function compromised in the vWF-deficient mice, but also that endothelial fragility may be increased.

$\beta 3$-deficiency results in placentation defects. A role for $\alpha v \beta 3$ in embryo implantation has been suggested (16). Our results indicate that implantation is not affected by $\beta 3$ integrin deficiency in mice and that the numbers of embryos found per litter do not differ between $\beta 3$-null and wild-type mice. In contrast, placental defects were evident in the $\beta 3$-null mothers. In addition to the hemorrhage under the Reichert's membrane, which was probably due to a combination of leakage of maternal blood vessels and defective platelet function, a second phenotype was observed. In approximately $20 \%$ of $\beta 3$ null maternally derived placentae the cell layers within the labyrinth appeared thickened and occluded sinus volume, thus decreasing efficient blood circulation and exchange of nutrients. This often led to necrosis within the labyrinth and compromised embryo survival. Thus, although previous work predicted that the $\beta 3$-knockout mice would suffer implantation defects, we have shown that this event is not affected, but that placental development and/or maintenance is abnormal. It is interesting that early embryos (around E10.5) of $\alpha \mathrm{v}$-knockout mice also suffer some placental defects where the labyrinth appears compact and the sinuses are reduced in size (44). These findings open the way to further investigations related to possible human placental defects that reduce fetal survival in humans. For example, preeclampsia is an important disease of pregnancy in which endovascular invasion is abrogated and cytotrophoblasts fail to adopt a vascular adhesion phenotype. In addition to other adhesion molecules, misexpression of $\beta 3$-integrin levels has been noted in cytotrophoblasts of preeclampsia patients $(45,46)$.

$\beta 3$-integrin deficiency does not prevent neovascularization in the mouse retina. A variety of antibody and peptide blocking studies have implied a role for $\alpha v \beta 3$ in neovascularization (13, 20-22). In the developing mouse retina neovascularization, occurring during the first two weeks after birth, is reduced by the administration of RGD peptides that selectively block $\alpha v \beta 3$ and/or $\alpha v \beta 5(23,24)$. Our data indicate that $\beta 3$-integrin deficiency does not prevent the neovascularization events in the developing mouse retina (Fig. 7). Whether functional compensation by other integrins such as $\alpha \mathrm{v} \beta 5$ may be occurring remains unclear, but at present we have no evidence for compensation in endothelial cells. It should be noted, however, that functional compensation is not occurring in $\beta 3$-null MEFs (Fig. 2), and, therefore, these data suggest that deficiency in $\beta 3$-integrins does not automatically imply compensation by other integrins.

The $\beta 3$ integrin-deficient mice represent a good model of the human disease Glanzmann thrombasthenia, replicating essentially all its established clinical features. This should provide opportunities for further studies of the consequences of mutations in the $\beta 3$-integrin gene using approaches not feasible in human patients. The results on these mice already reveal placentation defects that may also occur in human GT patients and/or may provide insights into preeclampsia of pregnancy. Our analyses of neovascularization of the retina suggest that the implications of antibody and peptide blocking experiments may have overestimated the importance of $\beta 3$ integrins in neovascularization. Further studies of this issue using these mice should prove informative and should also shed light on other physiological and pathological processes thought to involve $\beta 3$ integrins. These include angiogenesis (especially in tumour development), wound healing (47), restenosis (48), and bone remodeling (49). Preliminary data with $\beta 3$-null osteoclasts have shown that they have defective bone remodeling abilities in vitro and result in osteosclerotic lesions in vivo (McHugh, K.P., et al., manuscript in preparation).

\section{Acknowledgments}

We thank Martin Hemler for his generous gift of antibodies, and Stephen Robinson, Daniela Taverna, and Cecile Denis for their constant help and encouragement. This work was supported by the Howard Hughes Medical Institute and by grants from the National Institutes of Health National Heart, Lung, and Blood Institute (HL41484, to R.O. Hynes, and HL19278 and HL54469, to B.S. Coller); from Barnes-Jewish Hospital Foundation (to K.P. McHugh); from the National Institutes of Health National Institute for Arthritis and Rheumatism (AR32788 and AR42404; to S. Teitelbaum and F.P. Ross); from the Shriner's Hospitals for Children (15960, to S. Teitelbaum). K.M. Hodivala-Dilke was a fellow of the Human Frontiers Science Program and the Dystrophic Epidermolysis Bullosa Research Association, and R.O. Hynes is an Investigator of the Howard Hughes Medical Institute.

\footnotetext{
1. Hynes, R.O. 1992. Integrins: versatility, modulation, and signaling in cell adhesion. Cell. 69:11-25.

2. Kieffer, N., and Phillips, D.R. 1990. Platelet membrane glycoproteins: functions in cellular interactions. Annu. Rev. Cell Biol. 6:329-357.

3. Shattil, S.J. 1995. Function and regulation of the $\beta 3$ integrins in hemostasis and vascular biology. Thromb. Haemost. 74:149-155.

4. Du, X., and Ginsberg, M.H. 1997. Integrin $\alpha I I b \beta 3$ and platelet function. Thromb. Haemost. 78:96-100.

5. Lawler, J., Weinstein, R., and Hynes, R.O. 1988. Cell attachment to thrombospondin: the role of ARG-GLY-ASP, calcium, and integrin receptors. J. Cell Biol. 107:2351-2361.
} 
6. Engleman, V.W., et al. 1997. A peptidomimetic antagonist of the alpha(v)beta3 integrin inhibits bone resorption in vitro and prevents osteoporosis in vivo. J. Clin. Invest. 99:2284-2292.

7. Albelda, S.M., et al. 1990. Integrin distribution in malignant melanoma: association of the beta 3 subunit with tumor progression. Cancer Res. 20:6757-6764.

8. Cheresh, D.A., and Harper, J.R. 1987. Arg-Gly-Asp recognition by a cell adhesion receptor requires its $130-\mathrm{kDa}$ alpha subunit. J. Biol. Chem. 262:1434-1437.

9. Felding-Habermann, B., and Cheresh, D.A. 1993. Vitronectin and its receptors. Curr. Opin. Cell. Biol. 5:864-868.

10. Stefansson, S., and Lawrence, D.A. 1996. The serpin PAI-1 inhibits cell migration by blocking integrin alpha $\mathrm{V}$ beta 3 binding to vitronectin [comment]. Nature. 383:441-443.

11. Yip, P.M., Zhao, X., Montgomery, A.M., and Siu, C.H. 1998. The Arg-GlyAsp motif in the cell adhesion molecule L1 promotes neurite outgrowth via interaction with the alphavbeta3 integrin. Mol. Biol. Cell. 9:277-290.

12. Montgomery, A.M., et al. 1996. Human neural cell adhesion molecule L1 and rat homologue NILE are ligands for integrin alpha v beta 3. J. Cell. Biol. 132:475-485.

13. Brooks, P.C., Silletti, S., von Schalscha, T.L., Friedlander, M., and Cheresh, D.A. 1998. Disruption of angiogenesis by PEX, a noncatalytic metalloproteinase fragment with integrin binding activity. Cell. 92:391-400

14. Coller, B.S. 1995. Hereditary qualitative platelet disorders. In William's hematology. 5th ed. McGraw-Hill. New York, NY. 1364-1385.

15. Coller, B.S., Seligsohn, U., and Little, P.A. 1987. Type I Glanzmann thrombasthenia patients from the Iraqi-Jewish and Arab populations in Israel can be differentiated by platelet glycoprotein IIIa immunoblot analysis. Blood. 69:1696-1703.

16. Sutherland, A.E., Calarco, P.G., and Damsky, C.H. 1993. Developmental regulation of integrin expression at the time of implantation in the mouse embryo. Development. 119:1175-1186.

17. Korpelainen, E.I., and Alitalo, K. 1998. Signaling angiogenesis and lymphangiogenesis. Curr. Opin. Cell. Biol. 10:159-164.

18. Hanahan, D., and Folkman, J. 1996. Patterns and emerging mechanisms of the angiogenic switch during tumorigenesis. Cell. 86:353-364.

19. Varner, J.A., and Cheresh, D.A. 1996. Integrins and cancer. Curr. Opin. Cell. Biol. 8:724-730.

20. Brooks, P.C., et al. 1995. Antiintegrin alpha v beta 3 blocks human breast cancer growth and angiogenesis in human skin. J. Clin. Invest. 96:1815-1822.

21. Brooks, P.C., et al. 1996. Localization of matrix metalloproteinase MMP2 to the surface of invasive cells by interaction with integrin alpha $v$ beta 3. Cell. 85:683-693.

22. Drake, C., Cheresh, D., and Little, C. 1995. An antagonist of integrin alphavbeta3 prevents maturation of blood vessels during embryonic neovascularization. J. Cell. Sci. 108:2655-2661.

23. Friedlander, M., et al. 1996. Involvement of integrins alpha v beta 3 and alpha v beta 5 in ocular neovascular diseases. Proc. Natl. Acad. Sci. USA. 93:9764-9769.

24. Hammes, H.P., Brownlee, M., Jonczyk, A., Sutter, A., and Preissner, K.T. 1996. Subcutaneous injection of a cyclic peptide antagonist of vitronectin receptor-type integrins inhibits retinal neovascularization. Nat. Med. 2:529-533.

25. Crippes, B.A., et al. 1996 Antibody to $\beta 3$ integrin inhibits osteoclast-mediated bone resorption in the thyroparathyroidectomized rat. Endocrinology. 137:918-924

26. Horton, M.A., Taylor, M.L., Arnett, T.R. and Helfrich, M.H. 1991. Arg-glyasp (RGD) peptides and the anti-vitronectin receptor antibody 23C6 inhibit dentine resorption and cell spreading by osteoclasts. Exp. Cell Res. 195:368-375

27. Ross, F.P., et al. 1993. Interactions between the bone matrix proteins osteopontin and bone sialoprotein and the osteoclast integrin $\alpha v \beta 3$ potentiate bone resorption. J. Biol. Chem. 268:9901-9907.

28. Marcantonio, E.E., and Hynes, R.O. 1988. Antibodies to the conserved cytoplasmic domain of the integrin beta 1 subunit react with proteins in vertebrates, invertebrates, and fungi. J. Cell Biol. 106:1765-1772.

29. Hynes, R.O., et al. 1989. Integrin heterodimer and receptor complexity in avian and mammalian cells. J. Cell Biol. 109:409-420.

30. DiPersio, C., Shah, S., and Hynes, R. 1995. alpha3 beta1 integrin localizes to focal contacts in response to diverse extracellular matrix proteins. $J$. Cell. Sci. 108:2321-2336.

31. George, E.L., et al. 1993. Defects in mesoderm, neural tube and vascular development in mouse embryos lacking fibronectin. Development. 119:1079-1091.

32. George, E.L., and Hynes, R.O. 1994. Gene targeting and generation of mutant mice for studies of cell- extracellular matrix interactions. Methods Enzymol. 245:386-420.

33. Frenette, P.S., Johnson, R.C., Hynes, R.O., and Wagner, D.D. 1995. Platelets roll on stimulated endothelium in vivo: an interaction mediated by endothelial P-selectin. Proc. Natl. Acad. Sci. USA. 92:7450-7454.

34. Beer, J.H. and Coller, B.S. 1989. Evidence that platelet glycoprotein IIIa has a large disulfide bonded loop that is susceptible to proteolytic cleavage. J. Biol. Chem. 264:17564-17573.

35. Laemmli, U.K. 1970. Cleavage of structural proteins during the assembly of the head of bacteriophage T4. Nature. 227:680-685.

36. Dejana, E., Quintana, A., Callioni, A., and de Gaetano, G. 1979. Bleeding time in laboratory animals. III - Do tail bleeding times in rats only measure a platelet defect? (the aspirin puzzle). Thromb. Res. 15:199-207.

37. Subramaniam, M., et al. 1996. Defects in hemostasis in P-selectin-deficient mice. Blood.87:1238-1242.

38. Bronza, J.P. 1990. Shwartzman reaction. Semin. Thromb. Hemost. $16: 326-332$

39. Hogan, B., Beddington, R., Constantini, F., and Lacy, E. 1994. Manipulating the mouse embryo. 2nd ed. Cold Spring Harbor Laboratory Press. Cold Spring Harbor, NY. 258-259.

40. D'Amato, R., Wesolowski, E., and Smith, L.E. 1993. Microscopic visualization of the retina by angiography with high-molecular-weight fluorescein-labeled dextrans in the mouse. Microvasc. Res. 46:135-142

41. Coller, B. S., Cheresh, D. A., Asch, E., and Seligsohn, U. 1991. Platelet vitronectin receptor expression differentiates Iraqi-Jewish from Arab patients with Glanzmann thrombasthenia in Israel. Blood. 77:75-83.

42. French, D.L., and Coller, B.S. 1997. Hematologically important mutations: Glanzmann thrombasthenia. Blood Cells Mol. Dis. 23:39-51.

43. Denis C., et al. 1998. A model of severe von Willebrand disease: Defects in hemostasis and thrombosis. Proc. Natl. Acad. Sci. USA. 95:9524-9529.

44. Bader, B.L., Rayburn, H., Crowley, D., and Hynes, R.O. 1998. Extensive vasculogenesis, angiogenesis and organogenesis precede lethality in mice lacking all $\alpha_{\mathrm{v}}$ integrins. Cell. 95:507-519.

45. Zhou, Y., Damsky, C.H., and Fisher, S.J. 1997. Preeclampsia is associated with failure of human cytotrophoblasts to mimic a vascular adhesion phenotype. One cause of defective endovascular invasion in this syndrome? J. Clin. Invest. 99:2152-2164.

46. Zhou, Y., et al. 1997. Human cytotrophoblasts adopt a vascular phenotype as they differentiate. A strategy for successful endovascular invasion?. J. lin. Invest. 99:2139-2151.

47. Sepp, N.T., et al. 1994. Basic fibroblast growth factor increases expression of the alpha v beta 3 integrin complex on human microvascular endothelial cells. J. Invest. Dermatol. 103:295-299.

48. Panda, D., et al. 1997. Potential roles of osteopontin and $\alpha v \beta 3$ integrin in the development of coronary artery restenosis after angioplasty. Proc. Natl. Acad. Sci. USA. 94:9308-9313.

49. Li, C.F., Ross, F.P., Cao, X., and Teitelbaum, S.L. 1995. Estrogen enhances alpha $v$ beta 3 integrin expression by avian osteoclast precursors via stabilization of beta 3 integrin mRNA. Mol. Endocrinol. 9:805-813. 